\title{
Measures in Construction of the System of Citizen Participation in Decision Making in China
}

\author{
Xiaorong $\mathrm{Mi}^{*}$ and Yunshan Song \\ Institute of Marxism, Southwest University, Chongqing, China
}

\begin{abstract}
Citizen participation in decision making is the core of modern democratic politics. And an important measurement indicator to judge the condition of democracy in a country is to see its citizens' political freedom degree and right to participate in decision making. In the past few years, the Chinese government has proposed the objective of political civilization and social construction. In order to fulfill this objective, it is necessary to ensure and implement citizens' right to participate in decision making and to make relevant system construction.
\end{abstract}

Keywords: Citizen, participation in decision making, political civilization, system construction

\section{Introduction}

With development of the reform and opening up in China and improvement of social and economic life level, the consciousness of its citizens in protecting their own interests is also continuously enhanced and people's awareness of safeguarding their own interests by means of participating in a political decision making also becomes more and more intensified. Nevertheless, due to differences of different groups and classes in their interests, a variety of interest conflicts exist between different stakeholders. If the Chinese government is unable to provide appropriate solutions at the level of system, then the conflict of interests between different people might be intensified. As a consequence, the citizens might choose to resort a variety of extreme means to safeguard their own interests, which may make the society trapped into a disorderly and chaos condition. Thus, it is the essential requirement to set up a legal and orderly system of citizen participation in decision making, which is also an effective approach to fulfill citizens' wish to be the mater of the country and is a vigorous guarantee to realize social harmony.

\section{Problems Existing in the Process of Current Institutionalization Construction}

With the movement of reform in Chinese political system, the right of citizens to participate in decision making has received due attention and has begun to gradually stepped to institutionalization. However, there still exist a lot of problems in the process of

\footnotetext{
${ }^{*}$ Corresponding author
}

construction of the system of Chinese citizen participation in decision making. And if these problems are not resolved in an appropriate way, then this might have a negative effect on the relationship between the CPC and the public and on the social stability.

\section{The self-consciousness of citizen participation}

Citizens are the subject of political participation. In the process of administrative decision making by the government and the country, the consciousness of citizens in participation and their capacity in participation have a direct effect on formation and completion of institutionalization of citizen participation in decision making. Although both the consciousness and capacity of Chinese citizen participation in decision making has gained great improvement compared with that before the reform and opening up, and, construction of its institutionalization has also been conducted to a certain extent, there is still a large gap between the reality and the requirement to fulfill democratic politics and political civilization. We attribute this to the following two reasons.

On one hand, the self-consciousness of Chinese citizen participation in decision making is weak. China has had the tradition of feudal autocracy for several thousand years. Under the influence of the feudal thought, the citizens are accustomed to resorting to traditional means and non-institutionalized channels to propose their interest appeal and to resolve all kinds of social issues, instead of resorting to extant political and legal means to resolve these issues, so they are lacking in the consciousness of right and consciousness of participation in political decision 
making. Therefore, their usual response to the traditional bureaucrat authority is to silently recognize it and they also choose a negative attitude in treating their own right in political participation. As a result, construction of Chinese democratic politics, especially construction of institutionalization of citizen participation in decision making is seldom concerned.

On the other hand, Chinese citizens' capacity in participating in decision making is insufficient. Participation in decision making needs relative knowledge and calls for a particular procedure instead of disorderly participation. This requires the citizens to know what kind of rights they need to possess and what kind of obligations they need to perform, and requires the political participation subject (legal citizens) to possess corresponding knowledge and capacity and know about relevant laws and regulations as well as the procedure for political participation. Nevertheless, the reality makes us worried, as the vast majority of Chinese citizens have no knowledge in the right to participate in decision making, and even have no idea that they possess the right to participate in political decision making and have no knowledge in relevant laws and regulations involved in participation in decision making. Under such circumstance, the citizens have no capacity in fulfilling their own right to participate in decision making, which is also an obstacle in the process of constructing the system of citizen participation in decision making and is an issue that needs to be resolved urgently.

The government bureaucrat is indifferent to citizens' right to participate in decision making

At the time when the tradition of feudal autocracy leads to political numbness of citizens, it more gives rise to dictatorial and autocratic style of work and bad habit of the bureaucrat. Citizen participation in decision making clamors for conversation and negotiation with the public officials, then communication and cooperation between the two parties will be possible. Nonetheless, there are quite a large number of public officials at present in China who show indifference to the right and appeal of citizens and cast the right of citizens to participate in decision making behind their back. Where to discuss construction of institutionalization?

First of all, quite a lot of bureaucrats negate citizens' right to participate in politics and to participate in political decision making. In their eyes, political decision making is only a matter of the party holding power and the government and is the right of the power holders, one of their jobs. Thus, they are opposed to citizens' participation in any administrative decision making and completely exclude citizens from political participation and administrative decision making activities. This is quite unfavorable for establishment of the system of citizen participation in politics and citizens are unable to legally participate in the process of making a decision, let alone imposing any influence on the administrative decision making. Then, where is citizen participation? The top superiority have the final say on all decision makings, which is not an individual phenomenon, but which requires lots of efforts to be resolved.

Then, some public officials go through the motions in the process of citizen participation in decision making and just have a shallow taste. Compelled by pressure from some social public opinions or constrained by laws and regulations, some Party and government offices do adopt the pattern of citizen participation in making an administrative decision, but this is nothing more than going through the motions. Those citizens who actually participate in decision making are not the ones engaged in relevant interest, but the ones who have no interest relationship with the decision making. Thus, they don't really care about what kind of decisions are made, or even though they participate in the decision making, their participation is quite limited. What they do is just to put up their hands, cast a vote and go through the motions according to a presupposed procedure. This reality can be reflected in a lot of public hearings and elections held by the government in this country. Some electors take part in the election even though they have no idea about the qualification of the candidates. This is a common occurrence in a large number of this kind of formalism citizens.

\section{Serious deficiency of assurance of the system of Chinese citizen participation}

Citizen participation in decision making needs a whole set of matching improvement system. There ought to be relevant system to determine what kind of rights the citizens are supposed to possess in their participation in decision making to fulfill the need of their interest and what kind of obligations to perform to safeguard the need of others' interest. It also requires the system of citizen participation to prescribe what kind of procedures to go through in the process of citizen participation and how to participate to safeguard the order and legality of citizen participation in decision making. In the actual political life in China, there are quite a lot of defective systems, and some even exist in name only and fail to play their due role. All these serious problems need to be urgently resolved.

On one hand, the functions of the system are defective. The government has always been dedicated to democratic political construction and has set up 
quite a lot of systems of citizen participation in politics, such as, the System of People's Congress and the System of Political Consultation, which are an important approach of citizen participation in politics. However, in reality, these two systems have not played their function of entitling citizens to participate in politics. The System of People's Congress and the System of Political Consultation are supposed to be a bi-directionally running mechanism. One of their directions is to report the matters concerning the immediate interests of people that they are concerned with to the policy makers of the government. And when the government makes a policy, it has to take into consideration of the immediate interests people are concerned with. Otherwise, the System of People's Congress is entitled to call in question the legality of a government policy.

The other direction is to convey the political decision formulated by the government that reflects the willpower of people to the people and accept their supervision. However, in actual political life, the System of People's Congress and the System of Political Consultation are more inclined to a decision by the government and weaken the function of representatives of people's interests. They mostly serve as a voter for the government decision making and seldom raise an objection to its decision. This results in weakening of the function of the system of citizen participation in decision making and causes citizen participation in politics remain only as formality.

On the other hand, the legal assurance is defective. Indeed, some articles of law have stipulated the right of citizens to participate in politics, but there is not any special law to specifically prescribe in detail what kind of rights, on earth, the citizens have in the process of political participation, what kind of obligations the citizens are supposed to perform, what is the specific standard, what kind of requirements and what kind of procedures to follow, and so on. This makes the citizens at a loss when they participate in a specific political decision making and have no law to follow, so it seems that they are quite aimless. In terms of protecting citizen political participation, serious defect also exists in Chinese laws, which is mainly that there has not had any legal stipulation on any strict punishment on those who deprive the citizens of their right to participate in decision making, which makes the administrative decision making hard to be standardized. Thus, it can be seen that construction of institutionalization of citizen participation in decision making is quite urgent and there is still a long way to go.

\section{Measures in Construction of the System of Chinese Citizen Participation in Decision Making}

\section{To cultivate citizens' self-consciousness and capacity in participation}

\section{To cultivate citizens' consciousness through education}

The top priority in enhancing citizens' selfconsciousness in participation in decision making is to cultivate citizens' self-consciousness in the right through publicity and education. Only when the citizens come to realize that participation in decision making is a due right as a citizen, an important approach for the citizens to safeguard their own interest and is an unalienable right that the law endows with the people, then is it possible to arouse citizens' enthusiasm in participation in decision making, that an administrative decision can reflect the master position of the citizens and the system of citizen participation in politics can have its foundation of subject for its implementation. Then, it is necessary to cultivate citizens' self-consciousness in participation through publicity and education. Whether the citizens are able to successfully fulfill participation in decision making is an important indicator to judge whether the democratic system of the country is perfect, while awakening of the citizens' consciousness in participation is the precondition to judge whether the citizens are able to successfully fulfill participation in decision making. If the citizens have no consciousness in participation, then there is no space to discuss the subsequent activity of participation. Finally, it is necessary to cultivate citizens' consciousness in law through publicity and education. Only when the citizens learn to resort to the weapon of law to protect their right of participation and carry out their right of participation in accordance with the regulations of the law, can the system of citizen participation be carried out and implemented in a good order.

\section{Enhance citizens' capacity for participation}

The top priority in enhancing citizens' capacity in participation in decision making is to enhance citizens' cognitive capacity through education and training. Cognition of citizens in participation in decision making is the basis for citizens to participate in decision making. Then, what is participation in decision making? How to correctly exercise citizens' right to participate in decision making? What is the procedure for citizen participation in decision making? Only if we let citizens know about all these problems through education and training, can they successfully fulfill participation in decision making. Thus, the first thing is to enhance citizens' capacity of cognition in political participation. Secondly, we need to enhance citizens' capacity in participation through education and training. When the citizens participate in an 
administrative decision, whether they are able to fully participate in the making of the decision in the process of administrative decision making and then make the final decision reflect the willpower of the citizens and satisfy the need of the citizens requires the citizens to possess competitive participation capacity in the process of political participation.

Both cultivation of citizen consciousness in political participation and improvement of citizens' capacity in political participation call for the common efforts of the society, the country, the party in power and the citizens. First of all, it is necessary to build a stable social environment and to strengthen citizens' political participation and cultural construction in the stable social environment, so as to form an environment of universal education with political participation of citizens, to influence unconsciously each citizen and to enhance citizens' consciousness and capacity in political participation. Then, it is necessary to constantly push forward Chinese democratic political life and vigorously conduct publicity and education with citizen participation. Meanwhile, it is necessary to build a perfect environment for citizens to participate in decision making, which not only requires to strengthen education on citizens' consciousness in political participation, but also requires to provide guidance and education for citizens' practice to participate in administrative decision making. Finally, it is necessary for citizens to conduct self-education, continuously learn and accumulate relevant knowledge and laws and regulations and enhance their own consciousness and capacity in political participation.

\section{Citizens' right to participate in decision making and to change the concept of holding power}

\section{Citizens' right to participate in decision making}

The Party and the government officials ought to abandon the thought of bureaucratism, come to realize that citizen participation in one of the political rights of citizens instead of the right of the Party and the government officials, so they need to put in the right place their role in the national political life. They also need to respect the subject position of citizens in the national political life, set up a correct view of right and ensure the right of citizens to participate in decision making. It is also necessary for the Party and the government officials to avoid formalization of citizen participation in decision making. Formalization of citizen participation in decision making not only damages scientificity of administrative decision making, but is also blaspheme to the right of the citizens, an illegal behavior that impedes the citizens from legal exercise of their right to participate in decision making. Therefore, all the working staff in the Party and the government has to respect the right of citizens to participate in politics and ensure that the citizens have practically participated in the political decision making by the government.

\section{Establish a correct concept of holding power}

The Party and the government need to enlarge their education and management on the officials, improve their quality and level in power holding and rectify their wrong viewpoint on citizen political participation. We need to provide education and training for Party and government officials and request them to hold power with civilization, pursuant to the law and with democracy. They should provide explanation and response to the requests and questions proposed by citizens and lay emphasis on the interest of appeal from citizens. It is then necessary for them to strengthen the transparency of government decision making, actively accept supervision from citizens, prevent the Party and government officials from going through the motions in the process of participation and enabling the right of citizens to participate in decision making to really fall into place.

\section{Establish the system of citizen participation}

As a modern country in which democratic development is still relatively laggard, we need to continue to make efforts to improve our democratic system. We need to constantly strengthen the functions of the System of People's Congress and the System of Political Consultation and give full play to their functions in expressing people's proposal of interest and conveying people's appeal of interest instead of merely remaining at the superficial formality level. In the meantime, we also need to establish and improve such citizen participation systems as the letter petition system and public auditing to ensure smoothness of all kinds of channels for citizen participation. It is necessary to constantly improve relevant laws and regulations for citizen participation in decision making. The extant laws and regulations concerning assurance of citizen political participation are mostly general and abstract and are hard to comprehend and grasp in realistic application, so they fail to play the actual role in safeguarding citizens' right to participate. Hence, we have to pay attention to formulation of special, detailed and specific legal system and enable it to play a concrete guiding role and protecting role in citizens' participation in decision making.

In order to really establish a complete system, an important premise is that the country, and especially the party in power, to play its leading role. On one hand, this requires the representatives of the People's Congress and the representatives of the Political Consultation to take the initiative in shouldering the 
responsibility as a representative of the people's interest, to actively care about the matters that are in the most need and that are mostly concerned with and to convey accurately the interest need of people to the People's Congress or the Political Consultative Conference.

On the other hand, it is necessary for the country to enhance the discourse right of the People's Congress in a political decision making, and, instead of seeing the People's Congress as merely a formality, to really play the decisive role of the People's Congress in a political decision making, so as to really reflect the interest need of people in the political decision making. In terms of improving relevant laws concerning the citizen participation in decision making, the country needs to strengthen establishment of specific laws and regulations, give detailed stipulations on the procedure, mode and channel for citizens to participate in politics and enable it to have real powerful operability. Furthermore, it is necessary to enlarge the strength of power enforcement, impose constraint over and provide treatment for any illegal behavior that damages and deprives citizens' right in political participation and really ensure that the citizens' political right is independent of any damage.
To sum it up, citizens' participation in decision making is the foundation for construction of the country's democratic politics. Without citizens' political participation or expression of citizens' interest, democracy is out of the question. Therefore, construction of the system of citizen participation in decision making is the highest priority at present in China. Only if the system of citizen participation in decision making is established and improved, can the objective of a harmonious society in China be realized and can people more and more feel happy!

\section{References}

Chen, Fang. (2011). Citizen Participation in Public Service. China Social Sciences Publishing House.

Tutorial Textbook for the Report to the 18th National Congress of the Communist Party of China. People's Publishing House, November, 2012.

Wang, Lijing. (2011). Research of Institutionalization of Chinese Citizen participation. Wuhan University Press.

Wang, Wei, \& Niu, Meili. (2009). Citizen Participation. China Renmin University Press. 